\title{
Determining the genetic stability of micropropagated sugarcane using inter- simple sequence repeat markers
}

\author{
B.S. Hsie' ${ }^{1}$ J.Z. Brito ${ }^{2}$, M.X. Vila Nova1, L.R. Borges-Paluch ${ }^{3}$, M.V. Silva1 \\ and V.M.S.T. Donato ${ }^{1, \dagger}$ \\ ${ }^{1}$ Universidade Federal de Pernambuco, Recife, PE, Brasil \\ 'Laboratório de Genética Molecular, Instituto de Pesquisa Agropecuária, Bongi, \\ Recife, PE, Brasil \\ ${ }^{3}$ Laboratório de Microbiologia, Faculdade Maria Milza, Governador Mangabeira, \\ BA, Brasil \\ †'n memorian \\ Corresponding author: B.S. Hsie \\ E-mail: bety.bio@gmail.com
}

Genet. Mol. Res. 14 (4): 17651-17659 (2015)

Received June 24, 2015

Accepted September 18, 2015

Published December 21, 2015

DOI http://dx.doi.org/10.4238/2015.December.21.38

ABSTRACT. Sugarcane culture is an important source of income for the Brazilian economy. The aim of this study was to identify somaclonal variation in sugarcane varieties RB943365 and RB92579 arising from micropropagation using inter-simple sequence repeat (ISSR) DNA markers. The evaluated plants were generated from the in vitro propagation of shoot tips grown in MS medium supplemented with vitamins, myoinositol, glycine, and sucrose, without the use of growth regulators. Fifteen consecutive subcultures with intervals of 14 days were carried out, and DNA was extracted from young leaves obtained from each of the subcultures. The DNA was amplified with ISSR markers and separated by electrophoresis on $2 \%$ agarose gels. No evidence of polymorphism was observed in subcultures of the varieties analyzed, suggesting the absence of somaclonal 
variants. In this way, the ISSR marker was efficient at analyzing somaclonal variation, and in vitro propagation of sugarcane can be considered efficient for 15 consecutive subcultures of the varieties analyzed.

Key words: Saccharum officinarum; Somaclonal variants; Molecular markers

\section{INTRODUCTION}

The sugar from the sugarcane is consumed by approximately $70 \%$ of world and is an economically important cash crop in the tropical and subtropical regions of many countries. Approximately 20 million hectares of sugarcane are cultivated in more than 90 countries because of its high trade value (Rajeswari et al., 2009). In vitro propagation of sugarcane (Saccharum $\mathrm{spp}$ ) is an attractive alternative in breeding programs for the multiplication of varieties due to its time economy over conventional techniques, the excellent plant quality, and the genetic uniformity of seedlings (Cidade et al., 2006). Furthermore, a high rate of sugarcane multiplication can be achieved using tissue culture methods (Singh et al., 2008).

Therefore, innovative approaches involving cell and tissue culture possess significant promise for the successful clonal propagation of sugarcane by controlling problems faced during conventional breeding practices and multiplication procedures (Ali et al., 2012). Genetic and phenotypic variation among clonally propagated plants of a single donor clone is not required when the purpose is clonal propagation only; however, genetic variants occasionally occur from any tissue culture medium resulting in somaclonal or epigenetic variations in micropropagated plants (Patade and Suprasanna, 2009).

DNA regulation can be managed to exploit cellular changes on a whole plant level, or in vitro by several factors, such as nutrients, the effects of culture medium, prolonged use of growth regulators, establishment of callus cultures, and maintenance of culture conditions. These can be used to promote the dedifferentiation and after a new differentiation cell and further utilization of successful and subsequent plant regeneration (Singh et al., 2008).

Some authors have affirmed that the number of in vitro subcultures is an important factor to consider to control for somaclonal variation. Without specifying numbers, Krikorian et al. (1993) suggested that excessive numbers of subcultures may increase the rate of somaclonal variation in vitro. Therefore, it is believed that the age of the culture is related to increased genetic instability. However, even under good conditions, in vitro multiplication followed by successive subcultures can lead to somaclonal or epigenetic variation in the micropropagated plants.

The main mechanisms associated with somaclonal variation are point mutations, rearrangements, chromosomal recombination, mobilization of transposable elements, variation in ploidy level, and alterations in DNA methylation levels (Kaeppler et al., 2000; Jain, 2001). Changes in tissue morphology, as well as chromosomal, biochemical, and molecular changes have been observed in several plant species (Joyce et al., 2003).

Several advantages associated with the production of micropropagated seedlings include the selection of characteristics of interest, the use of small areas for seedling production, and obtaining plants that are free from pathogens (Santos et al., 2012). Therefore, it is necessary to establish longterm genetic uniformity in micropropagated shoots using molecular techniques. Molecular markers are widely used to detect and characterize somaclonal variations at the DNA level (Modgil et al., 2005).

Currently, genetic breeding programs seek to integrate classical techniques with selection 
assisted by molecular markers. In this scenario, inter-simple sequence repeat (ISSR) markers stand out as they can efficiently access variability at the DNA level, which contributes to increased heterosis during hybrid development (Toppa and Jadoski, 2013).

According to Grivet and Arruda (2002), molecular markers are important tools that can dissect complex genetically inherited characters and to directly detect genetic polymorphism. Molecular markers have been widely used to detect and characterize DNA somaclonal variation at the DNA level. Somaclonal variations occur at the DNA level and may arise in the annealing regions of an oligonucleotide; therefore, variation in these regions can be detected through analysis with ISSR markers. ISSR-polymerase chain reaction (PCR) is a technique that involves the use of microsatellite sequences as primers in PCR to generate multi-locus markers. ISSR markers are highly polymorphic and are useful in studies of genetic diversity, phylogeny, genetic marking, genome mapping, and evolutionary biology (Elmeer and Almalki, 2011).

Taking into account the current race to increase sugarcane production, it is necessary to search for quantitative traits, and to maintain good-quality crops in order to offer materials with better characteristics of interest that are genetically homogeneous. Given that bioplant generation uses a protocol based on a relatively limited number of nine subcultures in order to avoid the appearance of somaclonal variation, several studies have used this protocol and have shown that culture age is directly associated with the occurrence of somaclonal variants. Thus, the purpose of this study was to investigate the existence of somaclonal variation in sugarcane varieties from micropropagation up until the 15th subculture, using ISSR DNA markers.

\section{MATERIAL AND METHODS}

\section{Vegetal material}

All vegetal material used including the RB92579 (variety D) and RB943365 (variety E) varieties, was provided by the Experimental Station Itapirema (Agronomic Institute of Pernambuco). Immature leaves used as a source of explants were collected from shoot buds, planted in trays containing sterilized Plantmax, and maintained in a germination chamber type BOD for about 20 days at a temperature of $35^{\circ} \pm 1^{\circ} \mathrm{C}$ and a photoperiod of $16 \mathrm{~h}$ of light.

\section{Micropropagation in vitro}

The main nutritive culture medium used was MS (Murashige and Skoog, 1962) supplemented with vitamins; thiamine, pyridoxine, and nicotinic acid $(0.5 \mathrm{mg} / \mathrm{L}$ each), mio-inositol $(0.1 \mathrm{~g} / \mathrm{L})$, glycine $(2 \mathrm{mg} / \mathrm{L})$, sucrose $(30 \mathrm{~g} / \mathrm{L})$ and agar $(6 \mathrm{~g} / \mathrm{L})$. The $\mathrm{pH}$ was adjusted to 5.7-5.8, and agar $(6 \mathrm{~g} / \mathrm{L})$ was used to establish sugarcane meristems. No agar was used to prepare the multiplication liquid MS. Before the explants were sectioned, the leaves were subjected to a sterilization process consisting of sodium hypochlorite at $2 \%(\mathrm{v} / \mathrm{v})$ for $5 \mathrm{~min}$, and $70 \%$ alcohol $(\mathrm{v} / \mathrm{v})$ for $1 \mathrm{~min}$, followed by three washes in sterile distilled water. The caulinares apex was isolated under aseptic conditions in a laminar flow hood using a magnifying glass. Several leaf primordia were removed until they were less than $1 \mathrm{~mm}$ in length and consisted of approximately two leaf primordia. They were then quickly transferred to main cultivation medium for meristem establishment in test tubes with a lid. Cultures were maintained in a growth chamber at a temperature of $20^{\circ}-27^{\circ} \mathrm{C}$ for 15 days in the dark and then for an equal period in the light, after which cultures were transferred to vials containing the multiplication MS liquid.

The first subculture was performed when the inoculated explant reached an appropriate 
size, which usually occurred about 15-20 days after transfer to the vial containing the main multiplication MS medium. Each plant was fractionated into 2-3 parts depending on the number of tillers encountered. Two-to-four tufts containing 3-5 seedlings were placed into a flask. The interval between other subcultures was exactly 15 days. In total, 15 subcultures were performed for each variety examined, and during each multiplication procedure an average of 100 randomly selected bottles containing vegetal material were collected in order to carry out molecular analyzes.

\section{Molecular analysis}

Genomic DNA was extracted using the method described by Ferreira and Grattapaglia (1998) from vegetal material obtained from each of the 15 subcultures. DNA was analyzed by agarose gel electrophoresis on $1.0 \%$ (w/v) gel, in TBE buffer (0.09 M Tris-borate and $0.002 \mathrm{M}$ EDTA), stained with SYBR Gold (1X; Invitrogen) at 80V for about $20 \mathrm{~min}$. Gels were visualized under ultraviolet light, and photographed in a digital image photo document Lpix (LCG). The DNA concentration was estimated by comparison with known molecular weight markers (low DNA mass ladder; Invitrogen).

To perform the initial PCR, optimized parameters were used including DNA concentrations, addition of magnesium chloride, number of cycles, and PCR annealing temperatures (Table 1). In addition, oligonucleotides were chosen based on them being polymorphic for the varieties of sugarcane tested (Almeida et al., 2009).

The DNA amplifications were performed on a thermocycler MJ Research, Inc., Programmable Thermal Controller PTC100 (Watetown, USA), in a final volume of $25 \mu \mathrm{L}$ for each reaction, containing $10 \mathrm{mM}$ Tris- $\mathrm{HCl}, \mathrm{pH} 8.0,2 \mathrm{mM} \mathrm{MgCl}, 100 \mu \mathrm{M}$ of each dNTPs, $0.2 \mu \mathrm{M}$ oligonucleotide from Operon Technologies, $1 \mathrm{U}$ of the enzyme Taq DNA polymerase, and $20 \mathrm{ng}$ DNA. The cycles were programmed for $2 \mathrm{~min}$ at $94^{\circ} \mathrm{C}$, followed by 30 or 35 cycles of $1 \mathrm{~min}$ at $94^{\circ} \mathrm{C} ; 1 \mathrm{~min}$ at $50^{\circ} \mathrm{C}$; and $1 \mathrm{~min}$ at $72^{\circ} \mathrm{C}$, followed by $7 \mathrm{~min}$ at $72^{\circ} \mathrm{C}$. The reaction products were separated by electrophoresis on $2 \%$ agarose gel in TBE buffer (Tris-borate 0.09 M and 0.002 M EDTA), stained with SYBR Gold (1X; Invitrogen), and photographed under UV light in a digital image photo document Lpix (Cruz, 2001).

\begin{tabular}{lcr}
\multicolumn{2}{c}{ Table 1. List of primers used for PCR. } & \\
\hline ISSR primers & Annealing temperature $\left({ }^{\circ} \mathrm{C}\right)$ & Cycles of PCR \\
\hline UBC-01 & $50^{\circ}$ & 35 \\
UBC-02 & $50^{\circ}$ & 35 \\
UBC-05 & $50^{\circ}$ & 35 \\
UBC-808 & $50^{\circ}$ & 35 \\
UBC-809 & $50^{\circ}$ & 35 \\
UBC-810 & $50^{\circ}$ & 35 \\
UBC-812 & $50^{\circ}$ & 35 \\
UBC-820 & $50^{\circ}$ & 35 \\
UBC-827 & $50^{\circ}$ & 35 \\
UBC-848 & $50^{\circ}$ & 35 \\
UBC-888 & $50^{\circ}$ & 30 \\
UBC-890 & $50^{\circ}$ & 35 \\
UBC-891 & $50^{\circ}$ & 35 \\
\hline
\end{tabular}

UBC, primer set. University of British Columbia, Vancouver, Canada.

\section{Data analysis}

Data were analyzed using the NTSYS pc.2.1 program. The amplified products were tabulated as 1 (presence) and 0 (absent) for each band. The genetic distance between genotype pairs was calculated based on the complement factor as defined by Jaccard similarity. 


\section{RESULTS AND DISCUSSION}

The direct regeneration method enables existing genetic heterogeneity present within cells in the form of different cytotypes to be exploited. To efficiently apply the direct regeneration system, regeneration of plants directly from explants presents an effective strategy to avoid or substantially reduce somaclonal variation (Lakshmanan et al., 2006). This was clearly shown by the clones regenerated in the present study.

During micropropagation, the quality of the vegetal material that accumulated in the subcultures decreased. The material started to show yellowing leaves, as well as lower and rapid tiller oxidation. According to Gaspar et al. (2000), the loss of organogenic capacity during in vitro cultivation may occur during successive subcultures. Although the plant regeneration capacity is initially very high, cells may gradually lose their potential following successive subcultures (Andreu and Marín, 2005; Cavusoglu and Sulusoglu, 2013).

At the end of the micropropagation phase, a large amount of vegetal material was yielded in each subculture, which was separately packed and arranged for selection and subculture in order to obtain genomic DNA for molecular analysis. Initially, samples from nine subcultures of each variety were used in order to select the most informative oligonucleotides. Thirteen oligonucleotides were tested and published by the University of British Columbia (UBC). Of these, five were selected and the amplification products provided clear and good repeatability in both varieties. Of these, 108 amplicons were obtained, averaging 21 amplicons per oligonucleotide.

Technical consistency was assessed by the analysis of two independent samples of each variety and with the use of five oligonucleotides. All loci analyzed were present in two independent extractions and a high degree of consistency was found using the ISSR technique in the study of DNA polymorphism in sugarcane. Similar results were obtained by Yang et al. (1996) in sorghum.

From 108 fragments generated in this study, 100\% monomorphic bands were observed in subcultures of the same variety, indicating that none of the five oligonucleotides used detected somaclonal variation when compared with the standard array plant (control plant) (Figures 1 and 2). Similar results were observed in pear by Erig and Schuch (2003). This result can be explained by the fact that the experimental material originated from explant tissues, in other words, via direct regeneration. Plants regenerated via direct organogenesis are more stable than those obtained from callus (Kamenickà and Rypák, 1989), with less risk of somaclonal variation and chimeras (D'Amato, 1977; Soares et al., 2014). Sugarcane was one of the first plants for which this was reported (Heinz and Mee, 1969; Larkin and Scowcroft, 1981), with variations found in cytogenetic and enzymatic traits as well as in stool appearance, stalk characteristics, and disease resistance. Since then, somaclonal variation in in vitro derived sugarcane has been consistently observed, particularly when plants are produced via a callus stage, which involves exposure to high levels of auxin (3-5 mg/L 2,4-D) and long culture periods (Abo-Elwafa, 2004; Snyman et al., 2011).

Hashmi et al. (1997), analyzed somaclonal variants derived from peach embryonic callus culture, and found 29\% polymorphic fragments (Cavusoglu and Sulusoglu, 2013). Shoyama et al. (1997) studied regenerated plantlets via direct somatic embryogenesis of Panax notoginseng and found evidence of genetic homogeneity when compared with the original plants.

Karp (1995) reported that certain genotypes appear to be more unstable in vitro than others. This shows that somaclonal variation is dependent on the genotype. Studies have shown the involvement of a genetic component in the predisposition to somaclonal variation. There are regenerated plants that have genotypes with higher rates than other abnormalities (Rodrigues et al., 2012). 


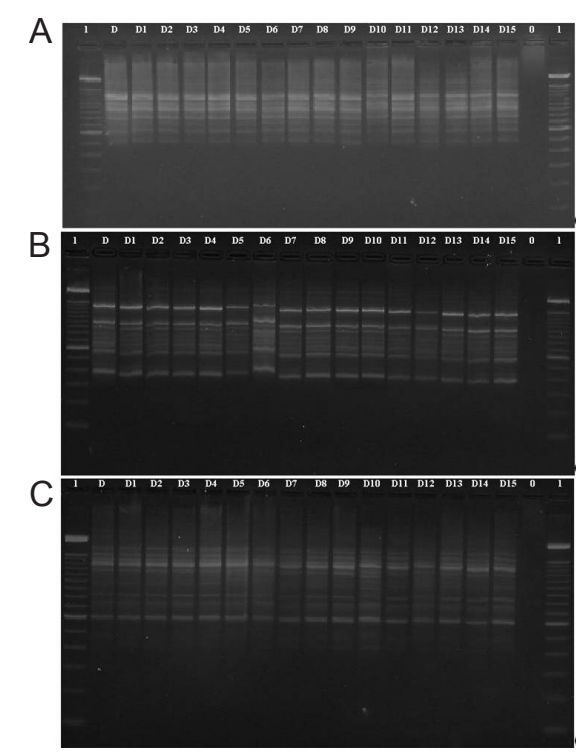

Figure 1. Electrophoretic pattern of variety D with UBC-type ISSR. Electrophoretic pattern obtained from the amplification of DNA from sugarcane variety D (RB92579) in each of the subcultures in the order listed (D1, D2, D3, etc.), where D is the mother plant, 0 is the negative control and 1 is the molecular weight marker (1-kb Ladder Plus), by respective primers: A. UBC 01; B. UBC 05; C. UBC 808. UBC, primer set, University British Columbia, Vancouver, Canada.

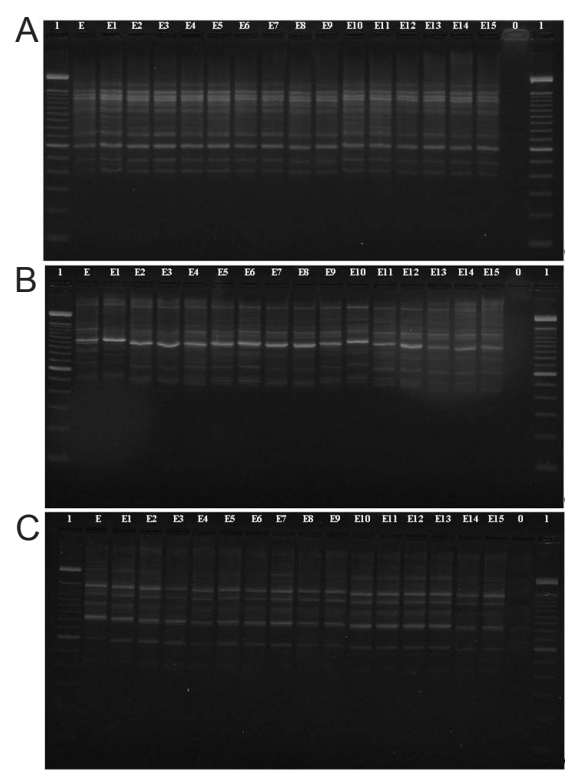

Figure 2. Electrophoretic pattern of variety E with oligonucleotide UBC-type ISSR. Electrophoretic pattern obtained by amplification of DNA from sugarcane variety E (RB943365) in each of the subcultures in the order listed (E1, E2, E3, etc.) where $E$ is the matrix plant, 0 is the negative control and 1 is the molecular weight marker (1-kb Ladder Plus) by the respective primers: A. UBC 808; B. UBC 810; C. UBC 827. 
Amplicons produced by ISSR markers were used to calculate the degree of genetic similarity among the varieties of sugarcane and between their respective subcultures. In order to evaluate the discriminating power of ISSR markers, an analysis was performed using the UPGMA method calculated from the Jaccard similarity coefficient, where the formation of two main groups was observed (Figure 3). These main groups were the varieties, which showed a low coefficient of similarity at $24 \%$. From each of these groups, one showed $100 \%$ similarity coefficient, which were the subcultures analyzed from each variety, thus demonstrating the total genotypic homogeneity between subcultures.

SSR and ISSR markers are useful in the identification of organisms and microorganisms due to their high reproducibility, and the speed and efficiency of their use when compared to other molecular markers. ISSR markers represent a simple technique with a high degree of polymorphism, reproducibility, and low cost. One example of an ISSR is microsatellites, which are very applicable in genetic studies of economically important organisms (Borba et al., 2005; Toppa and Jadoski, 2013).

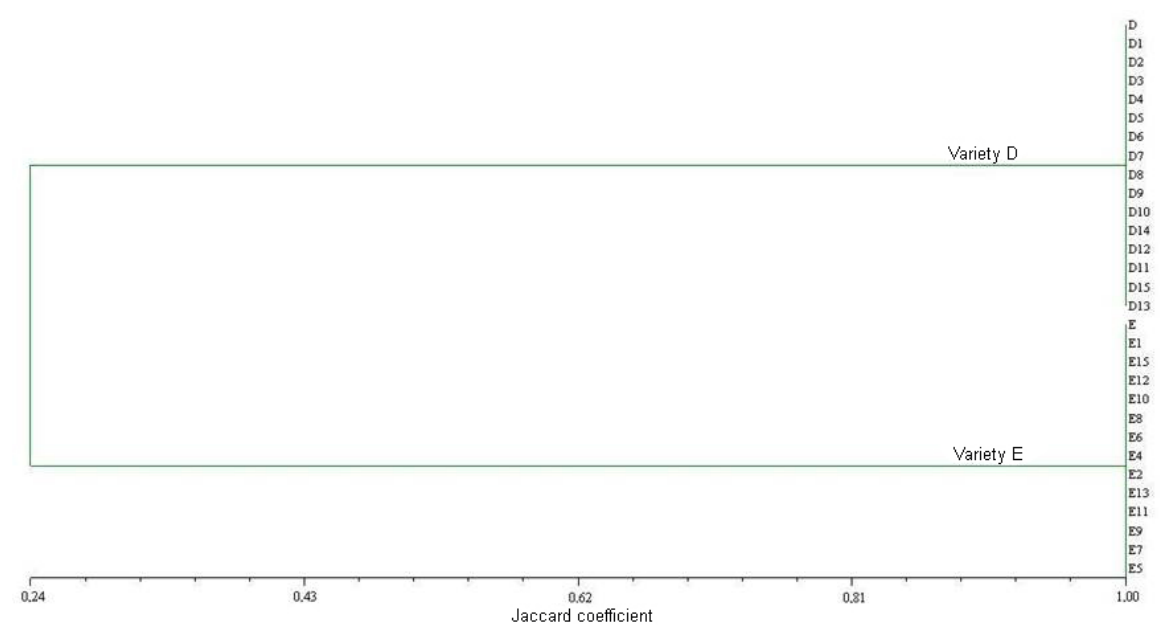

Figure 3. Dendrogram of sugarcane variety D (RB92579) and variety E (RB943365) and their respective subcultures. The dendrogram was built from the amplification products obtained using UBC oligonucleotides of ISSR type, using the UPGMA clustering method, based on the addition of the coefficient of similarity as defined by Jaccard.

The aim of this project was to test the protocol used in most biofactories using nine subcultures in order to provide a genotypic and loyalty-free material of somaclonal variants. Fifteen subcultures were tested, which is almost twice the number commonly used to remain within relatively safe margins. Analysis of the results confirmed the safety of the protocol used in biofactories; however, it is also safe when used according to the multiplication methodology applied in the present study.

The results shown in Figure 1 ( $\mathrm{A}, \mathrm{B}$ and $\mathrm{C}$ ) show that the isolates are monoclonal, meaning that they are genetically close or belong to a single clone of cells. This demonstrates the importance of ISSR markers in order to obtain these results. To confirm this genetic approach, the UPGMA program was used to produce the dendrogram (Figure 3), from which two genetically similar groups were observed, confirming the results shown in Figure 1.

Lakshmanan et al. (2007) used ISSR and RAPD (random amplified polymorphic DNA) markers to analyze genetic variation in micropropagated banana plantlets (Nanjanagudu Rasabale variety) and detected similarities between marker profiles. In this study, proving the applicability of ISSR markers was essential to confirm similarities between the genetic profiles. 
In conclusion, the use of an ISSR marker was efficient at detecting DNA polymorphism in sugarcane. From the dendrogram analysis, an intervarietal low coefficient of similarity was found as well as a high degree of intravarietal similarity. The presence of somaclonal variants was not observed in any of the subcultures of the varieties analyzed, and reliable micropropagation of sugarcane was observed up to a limit of 15 subcultures.

These data confirm the security offered by biofactories that provide micropropagated sugarcane seedlings from the RB92579 and RB943365 varieties up to nine subcultures. In addition, under the same conditions and methodologies as applied in the present study, the micropropagation of sugarcane is reliable up to a limit of 15 subcultures and no somaclonal variants were found, however, arising depression in organogenic capacity of plants and loss of juvenility.

The micropropagation technique did not induce genetic variation at the loci analyzed until the 11th subculture based on the 11 microsatellite primers used in this study; however, more studies are needed to confirm the reliability of this information.

One of the main problems observed during in vitro culture is the presence of somaclonal variation among subclones of a parental line, which appear as a direct result of the culturing method in plant cells, tissues, or organs. Optimal analysis of the genetic stability of seedlings can be performed using a combination of two types of markers that amplify different regions of the genome (Martins et al., 2004; Corral-Martínez and Seguí-Simarro, 2012).

Working on kiwi plantlets, Palombi and Damiano (2002) suggested that the use of other techniques in addition to DNA amplification would be advantageous to evaluate somaclonal variation. Thus, in the present project, two PCR-based techniques, RAPD and ISSR markers, were adopted to evaluate the clonal fidelity of banana seedlings. Based on the results, ISSR would be the most feasible to differentiate, because RAPD was unable to differentiate the genetic profiles

\section{REFERENCES}

Abo-Elwafa A (2004). In field assessment of somaclonal variability in sugarcane through callus culture. Assuit J. Agric. Sci. 35: $29-47$.

Ali S, Khan MS and lqbal J (2012). In vitro direct plant regeneration from cultured young leaf segments of sugarcane (Saccharum officinarum L.). J. Anim Plant Sci. 22: 1107-1112.

Almeida CMA, Lima SEM, Lima GSA, Brito JZ, et al. (2009). Caracterização molecular de cultivares de cana-de-açucar utilizando marcadores ISSR. Ciên. Agrotec. 33: 1771-1776.

Andreu P and Marín JA (2005). In vitro culture establishment and multiplication of the Prunus root stock Adesoto 101 ( $P$. insititia L.) as effected by the type of propagation of the donor plant and by the culture medium composition. Sci. Hort. 106: 258-267.

Borba RS, Garcia MS, Kovaleski A, Oliveira AC, et al. (2005). Dissimilaridade genética de linhagens de Trichogramma Westwood (Hymenoptera: Trichogrammatidae) através de marcadores moleculares ISSR. Neotrop. Entomol. 34: 565-569.

Cavusoglu A and Sulusoglu M (2013). In vitro propagation and acclimatization of pepino (Solanum muricatum). J. Food Agric. Environ. 11: 410-415.

Cidade DAP, Garcis RO, Duarte AC, Sachetto-Martins G, et al. (2006). Morfogênese in vitro de variedades brasileiras de canade-açúcar. Pesqui. Agropecu. Bras. 41: 385-391.

Corral-Martínez P and Seguí-Simarro JM (2012). Efficient production of callus-derived double haploids through isolated microspore culture in eggplant (Solanum melongena L.). Euphytica. 187: 47-61.

Cruz CD (2001). Programas Genes - versão programa Windows. Editora UFV, Viçosa.

D'Amato F (1977). Cytogenetics of differentiation in tissue and cell culture. In: Applied and fundamental aspects of plants cell tissue and organ culture (Reinert J and Bajaj YPS, eds.). Springer Verlag, Berlin, 343-357.

Elmeer K and Almalki A (2011). DNA finger printing of Prosopis cineraria and Prosopis juliflora using ISSR and RAPD techniques. Am. J. Plant Sci. 2: 527-534.

Erig AC and Schuch MW (2003). Avaliação da fidelidade genotípica por marcadores RAPDs de brotações de pereira (Pyrus communis L.) cv. Carrick, regeneradas in vitro. Ciênc. Rural. 33: 449-454.

Ferreira ME and Grattapaglia D (1998). Introdução ao uso de marcadores em análise genética. 3rd edn. EMBRAPA CENARGEN, Brasília. 
Gaspar T, Kevers C, Bisbis B, Franck, et al. (2000). Loss of plant organogenic totipotency in the course or in vitro neoplastic progression. In vitro Cell. Dev. Biol. Plant. 36: 171-181.

Grivet L and Arruda P (2002). Sugarcane genomics: depicting the complex genome of an important tropical crop. Curr. Opin. Plant Biol. 5: 122-127.

Hashmi G, Huettel R, Meyer R, Krusberg L, et al. (1997). RAPD analysis of variation variants derived from embryo callus cultures of peach. Plant Cell Rep. 16: 624-627.

Heinz DJ and Mee GWP (1969). Plant differentiation from callus tissue of Saccharum species. Crop Sci. 9: $346-348$.

Jain SM (2001). Tissue culture-derived variation in crop improvement. Euphytica 118: 153-166.

Joyce SM, Cassells AC and Jain SM (2003). Stress and aberrant phenotypes in vitro culture. Plant Cell Tissue Organ Cult. 74: 103-121.

Kaeppler SM, Kaeppler HF and Rhee Y (2000). Epigenetic aspects of somaclonal variation in plants. Plant Mol. Biol. 43: 179-188.

Kamenickà A and Rypák M (1989). The regeneration of Actinidia chinesis PI. cultured in vitro. Polnohospodarvo 35: 811-818.

Karp S (1995). Somaclonal variation as a tool for crop improvement. Euphytica 85: 295-302.

Krikorian AD, Heber Irizarry, Cronauer-Mitra SS and Rivera E (1993). Clonal fidelity and variation in plantain (Musa AAB) regenerated from vegetative stem and floral axis tips in vitro. Ann. Bot. 71: 519-535.

Lakshmanan P, Geijskes RJ, Wang L, Elliot A, et al. (2006). Developmental and hormonal regulation of direct shoot organogenesis and somatic embryogenesis in sugarcane (Saccharum spp. interspecific hybrids) leaf culture. Plant Cell Rep. 25: 1007-1015.

Lakshmanan V, Venkataramareddy SR and Neelwarne B (2007). Molecular analysis of genetic stability in long-term micropropagated shoots of banana using RAPD and ISSR markers. Electron. J. Biotechnol. 10: 106-113.

Larkin PJ and Scowcroft WR (1981). Somaclonal variation - a novel source of variability from cell cultures for plant improvement. Theor. Appl. Genet. 60: 197-214.

Martins M, Sarmento D and Oliveira MM (2004). Genetic stability of micropropagated almond plantlets as assessed by RAPD and ISSR markers. Plant Cell Rep. 23: 492-496.

Modgil M, Mahajan K, Chakrabati SK, Sharma DR, et al. (2005). Molecular analysis of genetic stability in micropropagated apple rootstock MM106. Sci. Hort. 104: 151-160.

Murashige T and Skoog F (1962). A revised medium for rapid growth and bio assays with tobacco tissue cultures. Physiol. Plant. 15: 473-497.

Palombi MA and Damiano C (2002). Comparison between RAPD and SSR molecular markers in detecting genetic variation in kiwifruit (Actinidia deliciosa A. Chev). Plant Cell Rep. 20: 1061-1066.

Patade VY and Suprasanna P (2009). An in vitro radiation induced mutagenesis - selection system for salinity tolerance in sugarcane. Sugar Tech. 11: 246-251.

Rajeswari S, Krishnamurthi M, Shinisekar S, Prem Anand S, et al. (2009). Performance of somaclones developed from intergeneric hybrids of sugarcane. Sugar Tech. 11: 258-261.

Rodrigues PHV, Ferreira FF, Ambrosano GMB and Gato AMG (2012). Propagação in vitro de tucumã do Amazonas. Ciên. Rural. 43: 55-59.

Santos TC, Arrigoni-Blank MF, Blank AF and Menezes MMLA (2012). Conservação in vitro de acessos de vertiver, Chyspogon zinzanioides (L.) Roberty (Poaceae). Biosci. J. 28: 963-970.

Shoyama Y, Zhu XX, Nakai R and Shiraishi S (1997). Micropropagation of Panax notoginseng by somatic embryogenesis and RAPD analysis of regenerated plantlets. Plant Cell Rep. 16:450-453.

Singh S, Anjum NA, Khan NA and Nazar R (2008). Metal-binding peptides and antioxidant defence system in plants: significance in cadmium tolerance. Abiotic stress and plant responses. IK International, New Delhi, 159-189.

Snyman SJ, Meyer GM, Koch AC, Banasiak M, et al. (2011). Applications of in vitro culture systems for commercial sugarcane production and improvement. In vitro Cell. Dev. Biol. Plant 47: 234-249.

Soares TC, Sales FMS, Santos JW and Carvalho JMFC (2014). Quitosana e fitorreguladores na indução da organogênese direta em cultivar de algodão colorido. Rev. Bras. Eng. Agríc. Ambient. 18: 839-843.

Toppa EVB and Jadoski CJ (2013). The use of molecular markers in plant breeding. Sci. Agr. Paranaensis 12: 1-5.

Yang W, de Olivera AC, Godwin I, Schertz KF, et al. (1996). Comparison of DNA marker technologies in characterizing plant genome diversity: variability in Chinese sorghums. Crop Sci. 36: 1669-1676. 